\title{
Study of the shelf-life of a mixed araça (Psidium guineensis Sw.) and marolo (Annona crassiflora Mart.) jam
}

\author{
Estudo da vida útil de geleia mista de araçá (Psidium guineensis Sw.) e marolo (Annona crassiflora Mart.)
}

Clarissa DAMIANI ${ }^{1 \star}$, Eduardo Ramirez ASQUIERI ${ }^{2}$, Moacir Evandro LAGE $^{3}$, Rodrigo Almeida de OLIVEIRA ${ }^{3}$, Flavio Alves da SILVA ${ }^{1}$, Douglas Endrigo Perez PEREIRA ${ }^{2}$, Eduardo Valério de Barros VILAS BOAS ${ }^{4}$

\begin{abstract}
The objective of this study was to add value to araça and marolo fruits by developing jams and verifying changes in their physical, chemical, and microbiological parameters during storage. The analyses were carried out every 2 months. From the results, it was shown that the levels of moisture (35.89 - 26.34\%), lipids $(0.43-0.27 \%)$, sucrose $(30.62-28.98 \%)$, total pectin $(0.83-0.50 \%)$, soluble pectin $(0.52-0.38 \%)$, total phenolic compounds (180.31 - $135.52 \mathrm{mg}$.GAE $\left.100 \mathrm{~g}^{-1}\right)$, and organic acids (401.1 - $68.5 \mu \mathrm{g} . \mathrm{g}^{-1}$ citric acid) decreased during storage. However, the levels of protein $(0.83-0.95 \%)$, carbohydrate $(62.52-72.5 \%$, calories $(257,11-295,931 \mathrm{kcal})$, fiber $(0.72-1.4 \%)$, total soluble sugar $(62.52-70.44 \%)$, reducing sugar $(32.05-41.41 \%)$, soluble solids $\left(68.4-72.18^{\circ} \mathrm{Brix}\right)$, consistency $(0.33-0.44 \mathrm{~N})$, total antioxidant potential $(11.3-22.63 \%)$, and color $\left(a^{*} 7.56-9.49\right.$, and $\left.b^{*} 8.63-10.49\right)$ increased during 1-year storage. The quality of the fruit jams studied was in accordance with the microbiological standards established by the Brazilian legislation. It was concluded that the mixed araça and marolo jam can be stored for 1 year without the addition of additives.

Keywords: savanna fruit; jam; storage; shelf-life.
\end{abstract}

\section{Resumo}

O objetivo do trabalho foi agregar valor ao araçá e marolo com o desenvolvimento de geleias e verificar as mudanças ocorridas em variáveis físicas, químicas e microbiológicas, durante o seu armazenamento. As análises foram realizadas, a cada 2 meses. Pelos resultados observados, verificou-se que os teores de umidade $(35,89-26,34 \%)$, lipídios $(0,43-0,27 \%)$, sacarose $(30,62-28,98 \%)$, pectina total $(0,83-0,50 \%)$, pectina solúvel (0,52 - 0,38\%), compostos fenólicos totais (180,31 - 135,52 mg.EAG $\left.100 \mathrm{~g}^{-1}\right)$ e ácidos orgânicos (401.1 - $68.5 \mu$ g.g-1 de ácido cítrico) reduziram durante o armazenamento. Contudo os teores de proteínas $(0,83-0,95 \%)$, carboidratos $(62,52-72,5 \%)$, valor calórico $(257,11$ - 295,931 kcal), teores de fibras $(0,72$ - 1,4\%), açúcar solúvel total (62,52 - 70,44\%), açúcar redutor (32,05 - 41,41\%) e sólidos solúveis $\left(68,4-72,18^{\circ}\right.$ Brix), bem como a consistência $(0,33-0,44 \mathrm{~N})$, o potencial antioxidante total $(11,3$ - 22,63\%) e os parâmetros de coloração $\left(a^{\star} 7,56-9,49\right.$ e b 8,63 - 10,49), apresentaram ascensão durante 1 ano de estocagem. As geleias estudadas conservaram-se dentro das normas microbiológicas estabelecidas pela legislação brasileira. A geleia mista de araçá e de marolo, portanto, pode ser armazenada por 1 ano, sem qualquer conservante químico.

Palavras-chave: frutos dos cerrados; geleia; estocagem; vida útil.

\section{Introduction}

In the economy of dynamic markets, new product development (NPD) is an essential factor for company survival, especially for food companies, which frequently need to release new products in order to remain ahead in an increasingly aggressive market. Currently, consumers have increased their expectations concerning product novelty and decreased their loyalty to traditional brands making the food market even more competitive.

One as yet little explored market possibility could be the development of products using fruits from the savanna, which have been consumed only by local populations during the harvest period as feedstock.

Fruits from the Brazilian guava (Psidium guineensis Sw) and maroleiro (Annona crassiflora Mart.) tree are an excellent alternative since they are already consumed by humans, both in the natural form and in the form of sweets, puddings, cakes, breads, cookies, jams, and liqueurs (ALMEIDA, 1998). The Brazilian guava, a native fruit known locally as araça belonging to the Myrtaceae family, bears fruit which are yellowish-white, yellow-green, pale yellow, or yellow when ripe. The pulp is fleshy, white, mucilaginous, sweet, slightly acidic, and very tasty and fragrant with numerous small seeds (MANICA, 2000). On the other hand, the Maroleiro fruit tree is a species native to the Brazilian savanna that bears fruits known variously as marolo,

\section{Received 30/8/2010}

Accepted 23/2/2012 (005017)

${ }^{1}$ Food Engineering Departament, Agronomy and Food Engineering School, Federal University of Goias - UFG, Rod. Goiânia, Km 0, Nova Veneza, CEP 74001-970, Goiânia, GO, Brazil, e-mail: damianiclarissa@hotmail.com

${ }^{2}$ Laboratory of Chemistry and Biochemistry of Food, School of Pharmacy, Federal University of Goias - UFG, Praça Universitária, 1a. Av. Laboratório de Química de Alimentos, Setor Universitário, CEP 74605-220, Goiânia, GO, Brazil

${ }^{3}$ Site in Food, School of Veterinary, Federal University of Goias - UFG, Rod. Goiânia, Km 0, Nova Veneza, CEP 74001-970, Goiânia, GO, Brazil

${ }^{4}$ Department of Food Science, Federal University of Lavras - UFLA, CP 37, CEP37200-000, Lavras, MG, Brazil

${ }^{*}$ Corresponding author

http://dx.doi.org/10.1590/S0101-20612012005000050 
araticum, or head-to-black, which are green in color before ripening and pale brown when mature (LORENZI, 1998). The flesh is slightly sweet with a pleasant aroma and can vary in color from white to yellow. The yellow-flesh variety is more widely accepted by the consumer market due to its more pronounced flavor and aroma (CARVALHO, 2002).

Considering the above, the purpose of this study was to add value to araçá and marolo fruits by developing a differentiated mixed jam using these fruits and studying the physical, chemical, and microbiological changes associated with the quality of the jam during twelve months of storage.

\section{Material and methods}

Fruits from the Brazilian guava and the maroleiro tree were harvested in 2008 in the State of Minas Gerais, Brazil. After selection, the fruits were washed to remove surface contamination, rinsed, and submerged in a $100 \mu \mathrm{l} . \mathrm{L}^{-1}$ sodium hypochlorite solution for 20 minutes. The araça fruits were then drained and immediately packed and frozen $\left(-18^{\circ} \mathrm{C}\right)$ for subsequent processing. The marolos were peeled, and the pulp was packed and frozen.

A mixed araça and marolo jam, known as extra-type jam, i.e., $50 \%$ fruit and $50 \%$ sugar, was formulated using the method described in the jam manufacturing manual (LOPES, 1985). Six kilograms of fruit juice (3.0 kg of each), $30 \mathrm{~g}$ of HMC (high methoxyl content) pectin, $60 \mathrm{~g}$ of citric acid (amount needed for the juice to reach $\mathrm{pH} \mathrm{3.2),} \mathrm{and} 6.2 \mathrm{~kg}$ of sugar were used forming a single batch. The araça and marolo jams were packed into glass jars, capped, inverted for 5 minutes, cooled, packed into cardboard boxes, and maintained at room temperature (approximately $25^{\circ} \mathrm{C}$ ) in the light for 1 year. The shelf life of the new product was monitored for one year every two months through physical, chemical, and microbiological analysis preparing three replicates as described below.

Moisture $\left(105^{\circ} \mathrm{C}\right.$ ), ash (incineration at $550{ }^{\circ} \mathrm{C}$ ), protein $(\mathrm{N} \times 0.65)$, lipids, dietary fiber (enzymatic-gravimetric), $\mathrm{pH}$, total acidity, soluble solids, and soluble sugars were determined according to Association of Official Analytical Chemists (1997) and the results expressed as percentages. The total and soluble pectin content was determined by a colorimetric method according to Bitter and Muir (1962); the total carbohydrates were determined according to Dubois et al. (1956), and the total caloric value was estimated as the Atwater conversion values as described by Wilson, Santos and Vieira (1982). The results were expressed as percentage and kcal, respectively.

The minerals were determined using a Varian SpectrAA 110 atomic absorption spectrometer; wavelength, slot, and gas mixture were calibrated specifically for each element. Atomic absorption standard (merck), diluted with deionized water, were used to construct calibration curves. The results were expressed in $\mathrm{mg} \cdot \mathrm{kg}^{-1}$.

Consistency was determined using a TAXT2 Stable Micro System Texturometer (Texture Techologies Corp.) and expressed in Newtons. The readings were taken at three distinct points in each jar of jam.
The organic acids were extracted according to Bazimarakenga, Simard and Leurox (1995), modified by Silva et al. (2001), and were identified and quantified by HPLC (High Performance Liquid Chromatography) using a Shimadzu CLASS LC 10 chromatograph equipped with a SPD-M10A UV detector at a wavelength of $230 \mathrm{~nm}$ and a C-18 reverse phase column $(150 \times 4.6 \mathrm{~mm})$. The sample injection volume was approximately $20 \mu \mathrm{L}$ and water containing $0.1 \%$ phosphoric acid at a flow rate of $1 \mathrm{~mL} /$ minute was used as mobile phase. The peaks corresponding to each acid were identified from their retention times using standard retention times for comparison. The results were expressed in $\mu \mathrm{g} \cdot \mathrm{g}^{-1}$

The antioxidant potential was determined by the DPPH method as described by Brand-Williams, Cuvelier and Berset (1995) and modified by Borguini and Torres (2009). The degree of discoloration of the DPPH radical at $517 \mathrm{~nm}$ by the action of the antioxidants was measured spectrophotometrically (Shimadzu mod. UV-1601 PC) in ethereal, alcoholic, and aqueous extracts at a concentration $0.2 \mathrm{mg} \cdot \mathrm{mL}^{-1}$. The results were expressed as DPPH discoloration/100 g.

The extraction of the alcoholic and aqueous compounds was carried out as described by Genovese et al. (2003) for the determination of total phenols using the Folin-Ciocalteu reagent. The determination of phenols was described by Zieliski and Kozowaska (2000), and the results were expressed as mg GAE. $100 \mathrm{~g}^{-1}$.

Color was determined using a Minolta CR-400colorimeter by determining the CIE parameters $L^{\star} a^{\star} b^{\star}$. The parameter $L^{\star}$ indicates how light or dark the jam is with values between 0 (totally black) and 100 (totally white).

The parameter $\mathrm{a}^{*}$ varies between -80 and +100 , the extremes corresponding to, green and red, respectively, and the parameter $b^{\star}$ varies from -50 to +70 , ranging from blue to yellow. The readings were taken at three distinct points in each pot of jam.

The microbiological analysis for filamentous fungi and yeasts, coliforms, and Salmonella sp. at 35 and $45^{\circ} \mathrm{C}$ followed the methodology proposed by the International Commission on Microbiological Specifications for Foods (1983).

A simple completely randomized design (CRD) with three replicates was used, and the influence of seven levels of the factor time $(0,2,4,6,8,10$, and 12 months) were evaluated. Each experimental plot consisted of one jar containing $150 \mathrm{~g}$ of jam.

The statistical analysis was carried out with the aid of the SISVAR software (FERREIRA, 2000) using the analysis of variance. Polynomial regression models were selected based on the significance of $\mathrm{F}$ test for each of the models tested considering the coefficient of determination also.

\section{Results and discussion}

Figure 1 shows the results obtained in the proximate analysis of the mixed araça and marolo jam.

Moisture, protein, fat, total carbohydrate content, and the caloric value were all influenced by the factor time $(\mathrm{p}>0.01)$. 

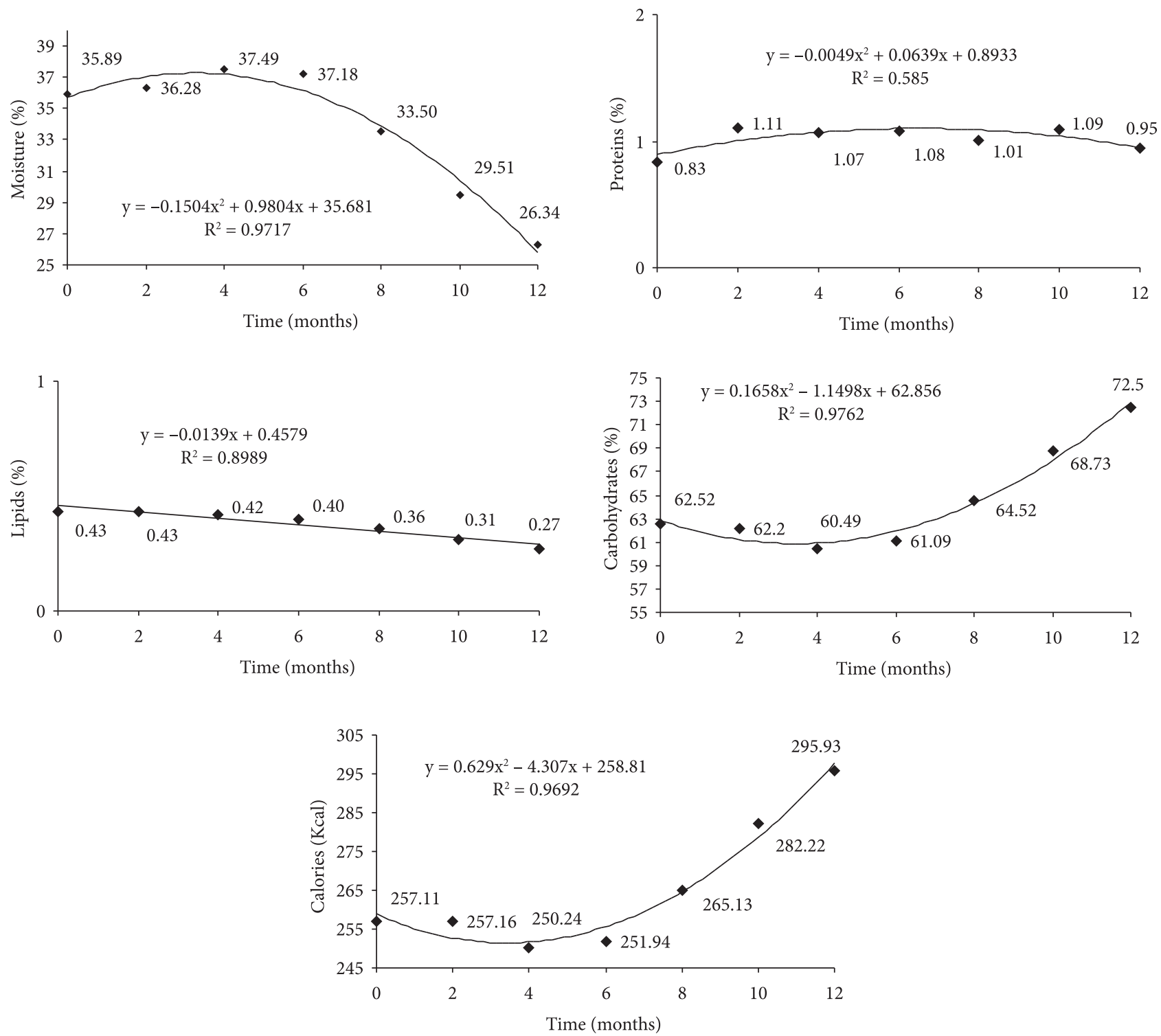

Figure 1. Proximate composition (wet basis) of mixed araça and marolo jam stored at room temperature $\left(25^{\circ} \mathrm{C}\right)$ in the light for 12 months.

The moisture content ranged from $35.89 \%$ (beginning of the experiment) to $26.34 \%$ (12 months) with a drop of approximately 27\%, as shown in Figure 1. This loss can be explained by the exchange of moisture between the inside and outside of the glass by desorption since in the dry season the average RH in Goiania was 27\% (GOIÁS, 2009). This exchange of moisture was also emphasized in studies by Jaime (2002) to evaluate glass packaging for storing coffee. Other factors are the superjunction chains forming the gel, trapping the free water and leaving it unavailable in the center (COULTATE, 2004; ORDONEZ, 2005), the presence of fungi such as Byssochlamys fulva, which degrades pectin (EVANGELISTA, 2000) leaving the galacturonic acid free to bind water molecules, and to a lesser extent, the Maillard reaction, which occurs at high temperatures $\left(25^{\circ} \mathrm{C}\right)$ in high-sugar products with low $\mathrm{pH}$ values using the water-free environment. This fact was also observed by Cardoso (2008) when assessing jambo jams during storage and by Rada-Mendoza, Olano and Villamiel (2002) when studying orange marmalade containing $33.4 \%$ moisture, $\mathrm{pH}$ value of 3.2 , protein content of $0.22 \%$, and furosine content of $119.4 \mathrm{mg} .100 \mathrm{~g} \mathrm{~g}^{-1}$ protein.

Despite the wide variation in moisture content, the values were within the standards established by the Brazilian legislation, which stipulates a maximum moisture content of $35 \% \mathrm{w} / \mathrm{w}$ for extra-type jams (BRASIL, 1978).

Considering the reduction in moisture content, other constituents such as proteins, carbohydrates, and calories increased since the medium became more concentrated. The protein content ranged from 0.83 to $0.95 \%$; the total carbohydrate content from 62.52 to $72.5 \%$, especially those represented by the amount of sugar included in the jam formulation ( $6.3 \mathrm{~kg}$ of sugar per $6.0 \mathrm{~kg}$ araça and marolo mixed juices), and the calories also increased during storage reaching values from 257.1 to $295.93 \mathrm{kcal}$ after 12 months of storage. 

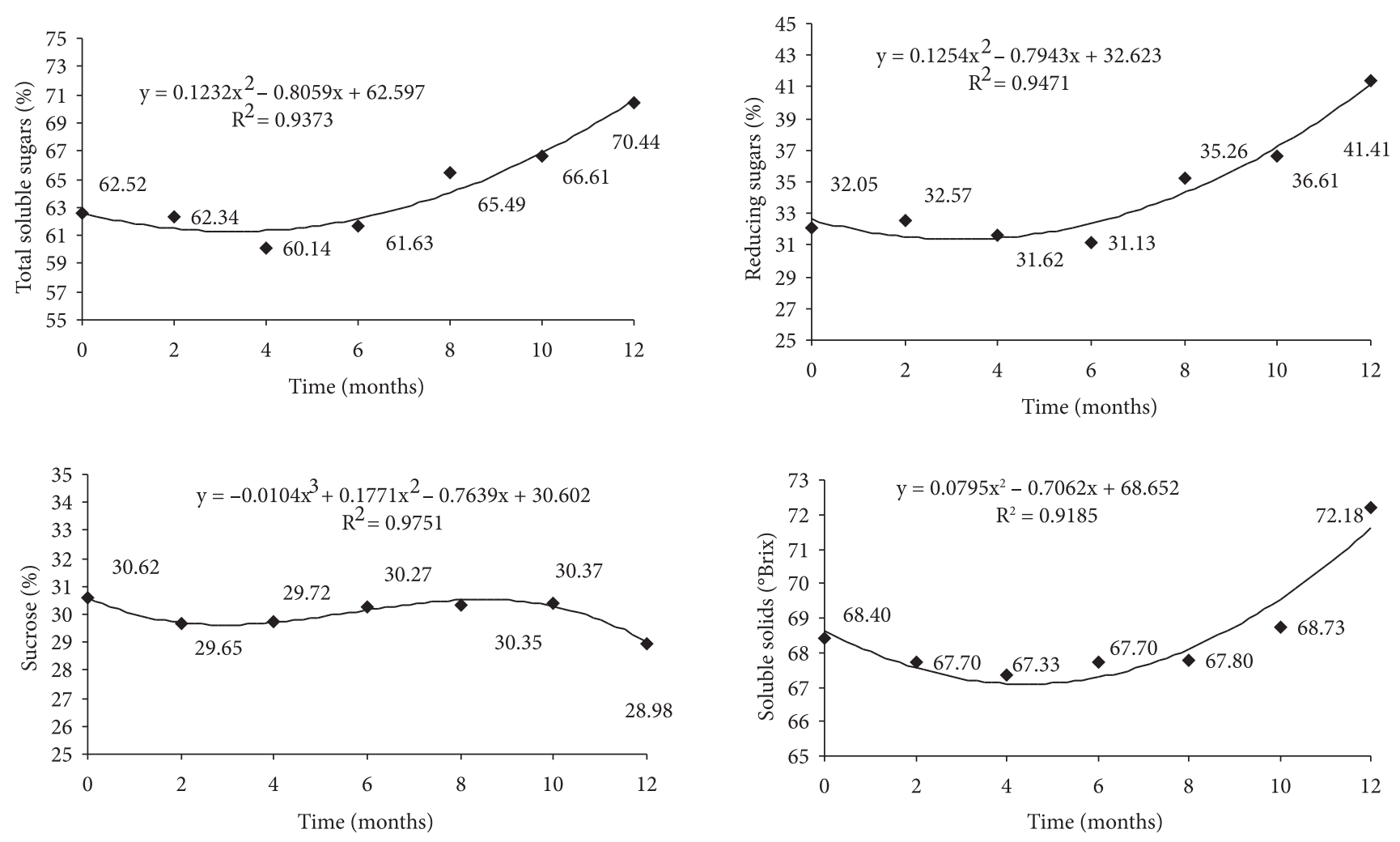

Figure 2. Average contents of total sugars (\%), reducing sugars (\%), sucrose (\%), and soluble solids ( ${ }^{\circ}$ Brix) present in the mixed araça and marolo jam stored at room temperature $\left(25^{\circ} \mathrm{C}\right)$ in the light for 12 months.
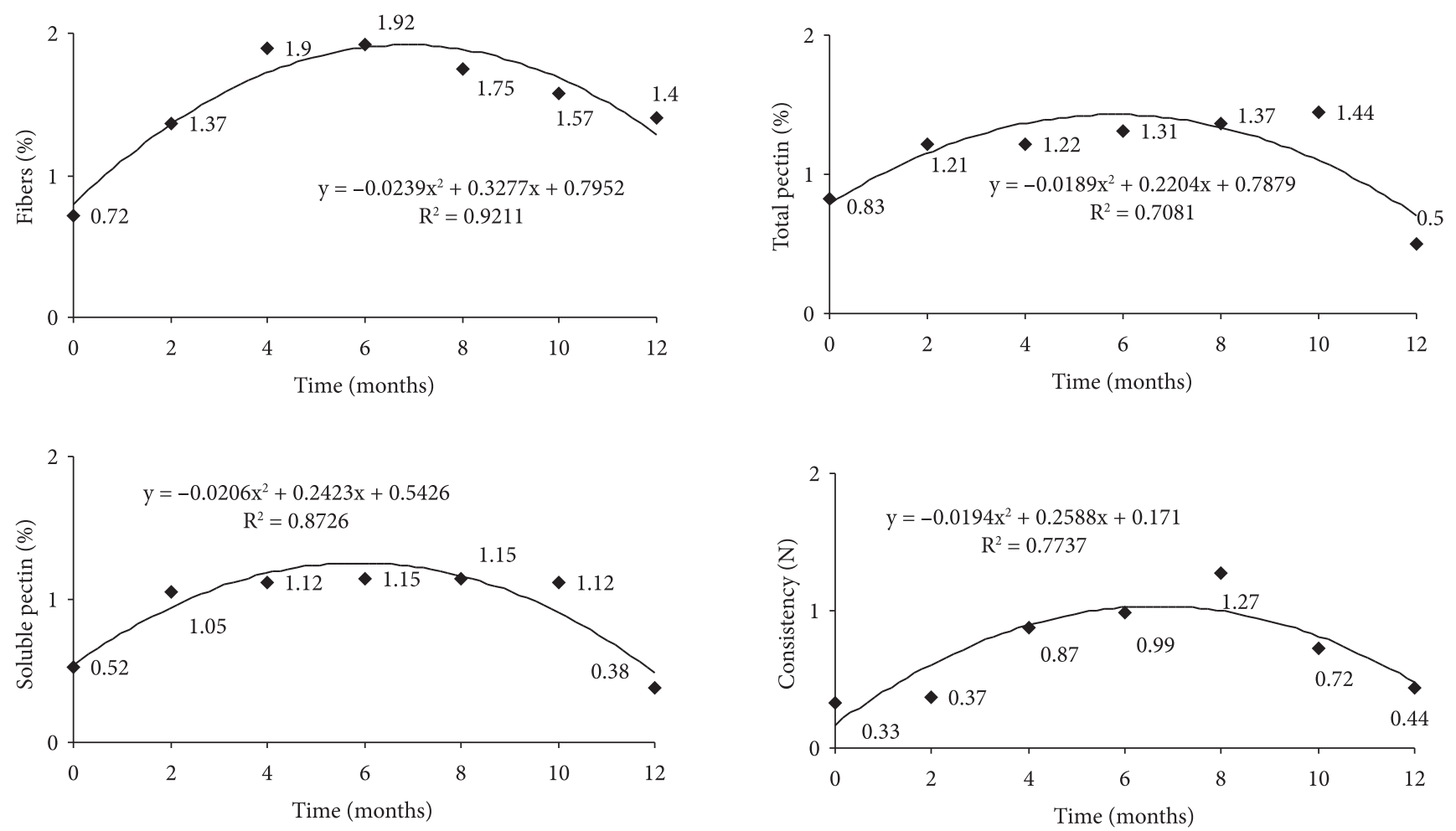

Figure 3. Average contents of fiber (\%), total pectin (\%) and soluble pectin (\%), and consistency (N) of mixed araça and marolo jams stored at room temperature $\left(25^{\circ} \mathrm{C}\right)$ in the light for 12 months. 
Unlike the the other parameters, lipid content decreased during storage (0.43 to $0.27 \%)$, possibly due to hydrolytic oxidation on account of the low mean $\mathrm{pH}$ value (3.3) (ARAUJO, 1994).

Time did not affect the ash content, which averaged $0.20 \%$. The predominant mineral in the mixed araça and marolo jam was potassium (1300 mg. $\mathrm{kg}^{-1}$ ), followed by sulfur (200 mg.kg ${ }^{-1}$ ), calcium (169 mg.kg $\left.{ }^{-1}\right)$, magnesium (105 mg. $\left.\mathrm{kg}^{-1}\right)$, phosphorus $\left(43.5 \mathrm{mg} \cdot \mathrm{kg}^{-1}\right)$, sodium $\left(30 \mathrm{mg} \cdot \mathrm{kg}^{-1}\right)$, manganese (6 mg. $\left.\mathrm{kg}^{-1}\right)$, iron $\left(3.2 \mathrm{mg} \cdot \mathrm{kg}^{-1}\right)$, copper $\left(1.63 \mathrm{mg} \cdot \mathrm{kg}^{-1}\right)$, zinc $\left(87 \mathrm{mg} \cdot \mathrm{kg}^{-1}\right)$, cobalt $\left(0.02 \mathrm{mg} \cdot \mathrm{kg}^{-1}\right)$, and molybdenum (0.01 mg.kg-1).

Analyzing the predominant minerals in the mixed jam (potassium, sulfur, calcium, and magnesium) and comparing them with the data for the jams from the individual fruits: araça jam (1200 mg. $\mathrm{kg}^{-1}$ potassium, $200 \mathrm{mg} \cdot \mathrm{kg}^{-1}$ of sulfur, $200 \mathrm{mg} \cdot \mathrm{kg}^{-1}$ calcium, and $94 \mathrm{mg} \cdot \mathrm{kg}^{-1}$ of magnesium) and marolo jam (1400 mg. $\mathrm{kg}^{-1}$ of potassium, $300 \mathrm{mg} \cdot \mathrm{kg}^{-1}$ of sulfur, $169 \mathrm{mg} \cdot \mathrm{kg}^{-1}$ of calcium, and $105 \mathrm{mg} \cdot \mathrm{kg}^{-1}$ magnesium), it seems that all values are within the same range, respecitively, although below the values for the recommended dietary intake (RDI) according to Institute of Medicine $(1997,2001)$, whose values

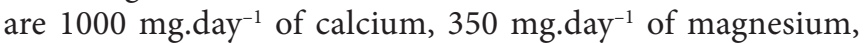
$10 \mathrm{mg}$.day ${ }^{-1}$ of zinc, $8 \mathrm{mg}$.day ${ }^{-1}$ of iron, $800 \mathrm{mg}^{- \text {day }^{-1}}$ of copper, and $700 \mathrm{mg}^{- \text {day }^{-1}}$ of phosphorus .

Time also affected $(\mathrm{p}>0.01)$ the total sugars, reducing sugars, sucrose contents, and the soluble solid contents (Figure 2) of the mixed araça and marolo jam.

The total sugar content also increased during the 1-year storage due to the reduction in the water content and ranged from 62.52 to $70.44 \%$. Throughout the experiment, the levels of reducing sugars were higher than those of sucrose. This can be explained by the cooking process used in the production of the jam, during which the sucrose undergoes a process of reversal in the acidic medium in which it is transformed partially or completely into glucose and fructose (invert sugar). This inversion of the sucrose is necessary to prevent crystallization, which can occur at certain times and also during storage (LOPES, 1985).This inversion of sucrose probably occurred during storage due to the low $\mathrm{pH}$ and was influenced by the concentration of acids such as citric, malic, and acetic acid (OETTERER; REGITANO-d'ARCE; SPOTO, 2006) and also by the relatively high ambient temperature $\left(25^{\circ} \mathrm{C}\right)$ throughout storage.

The soluble solids content ranged from 68.40 to $72.18^{\circ} \mathrm{Brix}$ and their major component is represented by the soluble sugars followed by the organic acids. The soluble solids content of the mixed jam was within the values stipulated by the legislation (BRASIL, 1978) (minimum of $68^{\circ} \mathrm{Brix}$ ).

The fiber, total pectin and soluble pectin contents, and the consistency of the mixed araça and marolo jam were also influenced by the time factor ( $p>0.01$ ), as can be seen in Figure 3.

The fiber content increased up to the 6th month of storage $(0.72$ to $1.92 \%)$ and then decreased (1.4\%). The increase can be explained by the reduction in moisture content. The total and soluble pectin contents showed the same behavior as the fiber content, ie, rise followed by fall. The total pectin content ranged from 0.83 to $1.44 \%$ (10th month) and decreased to $0.50 \%$ after 12 months of storage, whereas the soluble pectin content increased up to the 6 th month (0.52 to $1.15 \%)$, and then decreased reaching a content of $0.389 \%$ at the end of storage. The soluble pectin is formed of pectic acid, which, in the presence of water, forms colloidal solutions causing an additional reduction in the moisture content. The solubility of the pectin was $62.65 \%$ at time zero, $86.77 \%$ after 2 months, $91.8 \%$ after four months, $87.79 \%$ after 6 months, $83.94 \%$ after 8 months, $77.7 \%$ after 10 months, and finally $76 \%$. This breakdown of insoluble pectin into soluble pectin can be explained by the action of fungi such as Byssochlamys fulva, which produce pectinases that degrade pectin (EVANGELISTA, 2000).

Consistency increased up to the 8th month of storage $(0.33$ to $1.27 \mathrm{~N})$ and then decreased $(0.44 \mathrm{~N})$. These values are consistent with the observations made for the total and soluble pectin contents. The initial rise of up to five times is possibly due to the decrease in moisture content and the subsequent reduction to the the pectin-degrading fungi. According to Torrezan (1997), the consistency of jam is related to continuity (pectin concentration) and stiffness (sugar and acid).

Total acidity, $\mathrm{pH}$, and organic acids were influenced by time $(\mathrm{p}>0.01)$ as shown in Figure 4. The $\mathrm{pH}$ showed a slight tendency to decrease up to the 6th month of storage (3.31 to 3.27) returning to the initial value by the end of the 12 months of storage (3.33). Consequently, the total acidity followed the opposite pattern, with a slight increase from 1.17 to $1.27 \%$, probably due to the accumulation of other organic acids (shikimic, fumaric, oxalic, lactic, propionic) during storage then returning to the original value of $1.18 \%$ at the end of the experiment.

Vitamin $\mathrm{C}$ or ascorbic acid content showed a significant decrease during storage, being detectable for 4 months but were no longer detected until the end of the experiment (8.62 to $\left.0 \mu \mathrm{g} \cdot \mathrm{g}^{-1}\right)$. The initial vitamin $\mathrm{C}$ loss probably occurred due to chemical degradation involving the oxidation of ascorbic acid to dehydroascorbic acid, and it is known that heating increases the speed of the oxidation process (DEWANTO et al., 2002). Another likely explanation is the degradation of ascorbic acid due to the low moisture content and also the consumption in the Maillard reaction (FENNEMA, 2000; GIANNAKOUROU; TAOUKIS, 2003). Similarly, tartaric acid was no longer detectable after 2 months of storage.

The malic acid content decreased $71.09 \%$ (205.4 to $\left.59.4 \mu \mathrm{g} . \mathrm{g}^{-1}\right)$, citric acid $82.92 \%\left(401.1 \mu \mathrm{g} . \mathrm{g}^{-1}\right.$ to $\left.68.5 \mathrm{mg} . \mathrm{g}^{-1}\right)$, and acetic acid $27.13 \%$ (186.1 to $\left.135.6 \mu \mathrm{g} . \mathrm{g}^{-1}\right)$ during storage. The presence of acetic acid was probably due to the presence of fungi that fermented the sugar turning it into alcohol and $\mathrm{CO}_{2}$. In the presence of residual oxygen or the oxygen incorporated into the jam, the alcohol was converted into acetic acid (SNOWDON; OLIVER, 1996). The mixed araça and marolo jam also had health-enhancing substances such as antioxidants. These substances as well as the phenolic compounds were influenced by time ( $p>0.01)$, as shown in Figure 5 . 
There was an increase in the total antioxidant substances (ethereal extract, ethanol extract and aqueous extract) as compared to the values at the brginning of the experiment despite the decrease in their levels after the 8 th month. The total antioxidant potential ranged from 11.3 to $22.63 \%$ with a maximum of $54.8 \%$; the substances present in the ethereal extract ranged from 1.75 to $6.41 \%$ with a maximum of $20.07 \%$; those present in the ethanolic extract ranged from 3.82 to $5.53 \%$
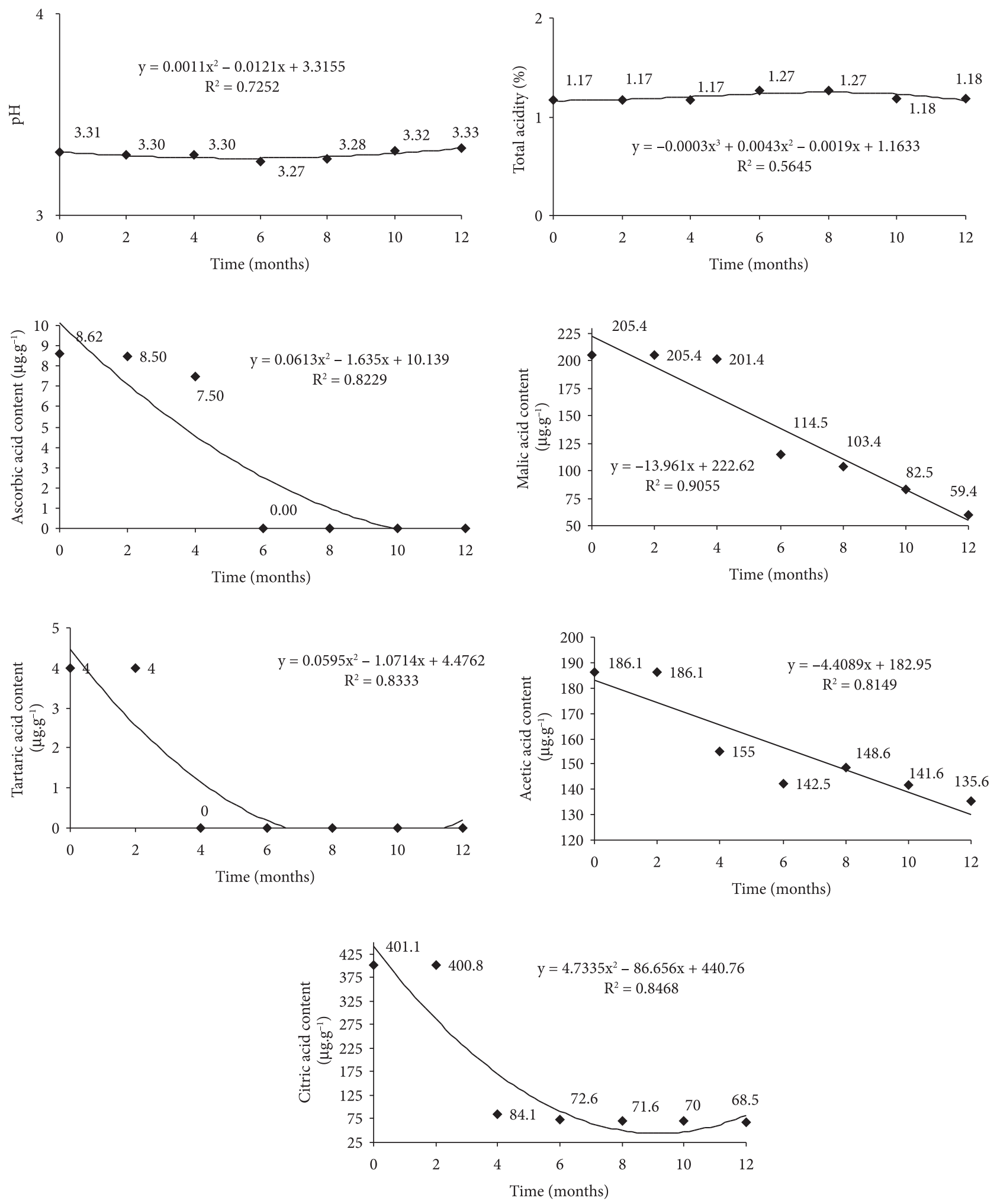

Figure 4. Average values for $\mathrm{pH}$, total acidity $(\%)$, ascorbic acid $\left(\mu \mathrm{g} \cdot \mathrm{g}^{-1}\right)$, malic acid $\left(\mu \mathrm{g} \cdot \mathrm{g}^{-1}\right)$, TA $\left(\mu \mathrm{g} \cdot \mathrm{g}^{-1}\right)$, acetic acid $\left(\mu \mathrm{g} \cdot \mathrm{g}^{-1}\right)$, and citric acid $\left(\mu \mathrm{g} \cdot \mathrm{g}^{-1}\right)$ in mixed araça and marolo jam stored at room temperature $\left(25^{\circ}\right)$ in the light for 12 months. 
with a maximum of $12.39 \%$; and finally the aqueous substances ranged from 5.73 to $10.89 \%$ with a maximum of $22.35 \%$. The presence of various antioxidant compounds in plant tissues, such as fruits and vegetables, makes it relatively difficult to measure the antioxidant activity of each component separately. The different solvents confirmed the maximum solubility of
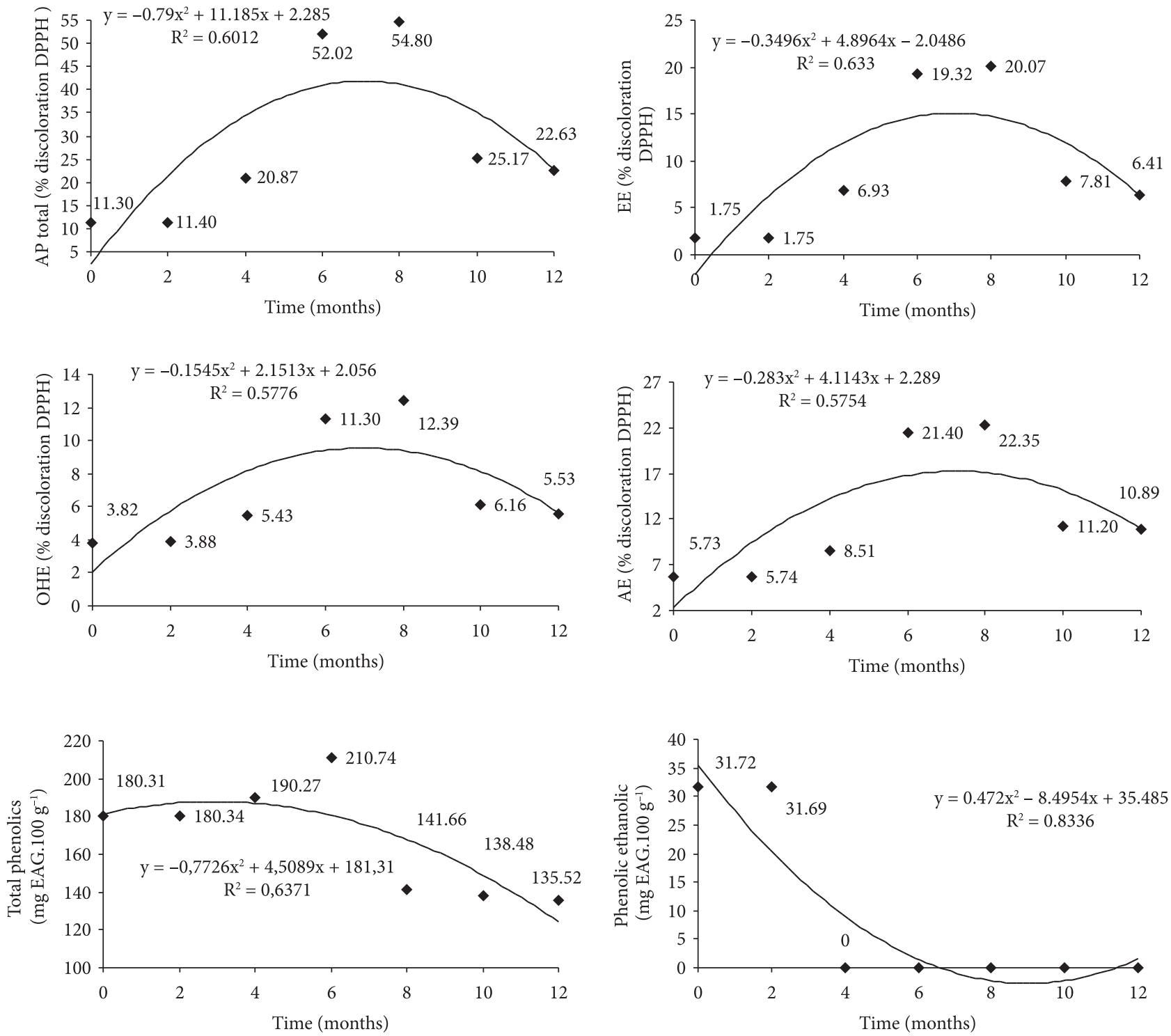

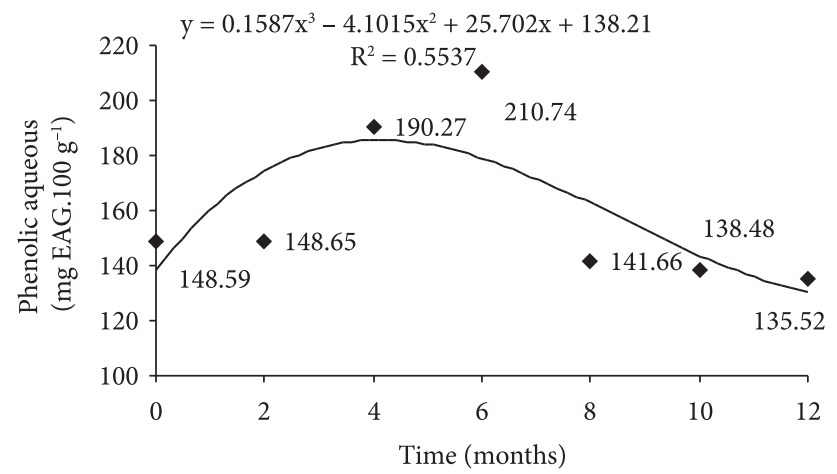

Figure 5. Total antioxidant potential (AP), ethereal extract (EE), ethanol extract (OHE), and aqueous extract (AE), expressed as the \% of decolorization of the DPPH radical, and the phenolic compounds in the aqueous extract, ethanol extract, and total extract (mg GAE $.100 \mathrm{~g}^{-1}$ ) in the mixed araça and marolo jam stored at room temperature $\left(25^{\circ} \mathrm{C}\right)$ in the light for 12 months. ${ }^{*} \mathrm{GAE}$ : gallic acid equivalent; Standard BHT $0.05 \mathrm{mg} \cdot \mathrm{mL}^{-1}=96.27 \%$ and $0.1 \mathrm{mg} \cdot \mathrm{mL}^{-1}=100 \%$. 

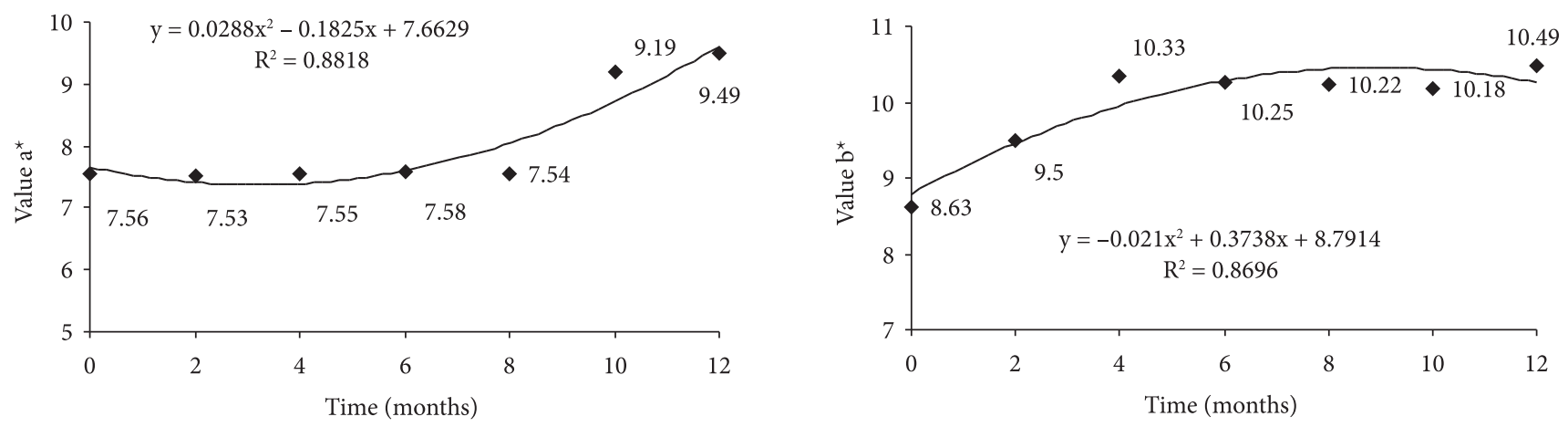

Figure 6. Color parameters ( $\mathrm{a}^{*}$ and $\mathrm{b}^{*}$ values) in the mixed araça and marolo jam stored at room temperature $\left(25^{\circ} \mathrm{C}\right)$ in the light for $12 \mathrm{months}$

antioxidants in the sample. The use of three solvents of different polarities, ethyl ether (2.9), ethanol (5.2), and distilled water (9) enables the dissolution of more polar (aqueous extract), intermediate polarity (ethanol extract), and nonpolar (ethereal extract) compounds, according to Borguini and Torres (2009).

Typical compounds that have antioxidant activity include the class of phenols, phenolic acids and their derivatives, flavonoids, tocopherol, phospholipids, phytic acid, ascorbic acid, pigments, and sterols (ROESLER et al., 2007). In addition, Zafrilla, Ferreres and Toms-Barbern (2001) studied the effect of the antioxidant ellagic acid during the storage of raspberry jams (Rubus idaeus) and found that its content doubled during processing and continued increasing after 6 months of storage. The same could have occurred with the mixed jams since ellagic acid is present in species from the savanna, such as marolo and araça (SOLON et al., 2000). The increase in antioxidant capacity may also have its origin in products from the Maillard reaction such as amino redutonas, which also show antioxidant effects (FENNEMA, 2000). The reduction at the end of 12 months of storage could possibly be explained by the degradation of anthocyanins resulting from temperatures above $20^{\circ} \mathrm{C}$ (storage was at $25^{\circ} \mathrm{C}$ ), according to a study by Wicklund et al. (2005) on the antioxidant capacity and color of strawberry jam during storage, or even due to the degradation of organic acids which show antioxidant activity reducing reactive oxygen species, as reported by Van den Berg et al. (2003).

With respect to the phenolic compounds, these were found in both the ethanolic and aqueous extracts, and their contents reduced during storage. At the beginning of the experiment, the concentration in the ethanolic extract was $31.72 \mathrm{mg}$ GAE. $100 \mathrm{~g}^{-1}$, but after 2 months storage, antioxidant substances were no longer detected. The initial concentration in the aqueous extract was $148.59 \mathrm{mg} \mathrm{GAE} .100 \mathrm{~g}^{-1}$, peaking at $210.74 \mathrm{mg}$ GAE. $100 \mathrm{~g}^{-1}$ half way through the experiment, and then decreasing to $135.52 \mathrm{mg}$ GAE. $100 \mathrm{~g}^{-1}$. The total phenolic compound content showed the same behavior increasing up to the 6th month of storage ( 180.31 to $210.74 \mathrm{mg} \mathrm{GAE} .100 \mathrm{~g}^{-1}$ ) and then reducing to a final value of $135.52 \mathrm{mg}$ GAE. $100 \mathrm{~g}^{-1}$. This loss of phenolic compounds can be explained by their instability at temperatures above $23{ }^{\circ} \mathrm{C}$ and close to $40{ }^{\circ} \mathrm{C}$ (temperature conditions to which the mixed jams were submitted), as shown by Chang et al. (2006) when evaluating the effect of storage temperature on the stability of phenolic compounds in fruits.
The color parameters ( $\mathrm{a}^{*}$ and $\mathrm{b}^{*}$ values) of the mixed araça and marolo jam were also influenced by the time factor ( $p>0.01)$ but the $L^{*}$ value was not affected during storage, maintaining an average of 28.47. The parameters $a^{*}$ and $b^{*}$ increased, as can be seen in Figure 6 .

The values for $\mathrm{a}^{\star}$ ranged from 7.56 to 9.49 and for $b^{*}$ from 8.63 to 10.49 . These values can be explained by the occurrence of the Maillard reaction and/or formation of hydroxymethylfurfural (HMF) due to the oxidation of vitamin C. This dark substance, was detected during the storage of fruit jams at $35^{\circ} \mathrm{C}$ in a study by Rada-Mendoza et al. (2004). In products with a high concentration of sugars, the reducing sugars bind to free amino acids or to those on the protein chains to form dark compounds. At $\mathrm{pH}$ values below 5 , an intermediate compound that undergoes dehydration is formed leading to the formation of HMF. This occurs during heating, i.e., during the production of the jams, and also during storage for extended periods. Apart from the reducing sugars, the carbonic fraction can originate from lipid oxidation, also fuelling the Maillard reaction (FENNEMA, 2000). Studying the stability of the color of jambo jams stored at 25 and $35^{\circ} \mathrm{C}$ for 180 days, Cardoso (2008) also showed an increase in these parameters concluding that when the jams were stored at a temperature of $35^{\circ} \mathrm{C}$, they suffered a more significant influence on the development of the yellow and red pigments as compared to storage at a temperature of $25^{\circ} \mathrm{C}$.

With respect to the microbiological aspects, there was no growth of Salmonella sp. or coliforms at 35 or $45^{\circ} \mathrm{C}$, but there was growth of fungi and yeasts during storage, as can be seen in Table 1.

Fungi and yeasts are the most common microorganisms found in products with high sugar concentrations and low $\mathrm{pH}$ values, but the values were within the limits allowed by RDC No. 12 of ANVISA (BRASIL, 2001), which establishes a maximum of $10^{4} \mathrm{CFU} \cdot \mathrm{g}^{-1}$ for fungi and yeasts in fruit jams. The reduction in the counts of filamentous fungi and yeasts during storage may have been due to the presence of antinutritional substances in the marolo pulp, as reported by Di Stasi and Hiruma-Lima (2002). Therefore, the results suggest the use of proper procedures in the processing of the jams, such as appropriate sanitization of the fruits and equipment, as well as the effectiveness of the conservation methods used since no preservatives were added to the mixed Brazilian guava and marolo jam processed. 
Table 1. Average results for the microbiological assays of mixed araça and marolo jam stored at room temperature $\left(25^{\circ} \mathrm{C}\right)$ in the light for 12 months.

\begin{tabular}{|c|c|c|c|c|}
\hline Time & $\begin{array}{l}\text { Fungi and yeasts } \\
\quad\left(\mathrm{CFU} \cdot \mathrm{g}^{-1}\right)^{1}\end{array}$ & $\begin{array}{l}\text { Salmonella } \\
\left(\mathrm{g} .25 \mathrm{~g}^{-1}\right)\end{array}$ & $\begin{array}{c}\text { Coliforms } \\
35^{\circ} \mathrm{C} \\
\left(\mathrm{MPN} \cdot \mathrm{g}^{-1}\right)^{2}\end{array}$ & $\begin{array}{c}\text { Coliforms } \\
45^{\circ} \mathrm{C} \\
\left(\mathrm{MPN}^{-1} \mathrm{~g}^{-1}\right)\end{array}$ \\
\hline 0 & Absent & Absent & Absent & Absent \\
\hline 2 & $8 \times 10^{3}$ & Absent & Absent & Absent \\
\hline 4 & $1 \times 10^{2}$ & Absent & Absent & Absent \\
\hline 6 & $1 \times 10^{2}$ & Absent & Absent & Absent \\
\hline 8 & $1 \times 10^{2}$ & Absent & Absent & Absent \\
\hline 10 & $1 \times 10^{2}$ & Absent & Absent & Absent \\
\hline 12 & $1 \times 10^{2}$ & Absent & Absent & Absent \\
\hline
\end{tabular}

\section{Conclusions}

The combination of araça with marolo for the production of jam shows overall positive results although some changes occurred during storage in the levels of moisture, lipid, sucrose, total pectin, and soluble pectin; phenolic compounds and organic acids decreased, whereas the levels of protein total carbohydrates, calories, total soluble sugar, reducing sugar, fiber, $\mathrm{pH}$ value, $\mathrm{a}^{*}, \mathrm{~b}^{*}$ values, and antioxidants increased.

The $L^{*}$ value and ash content were not influenced by the time factor, and the microbiological parameters were within the standards established by the Brazilian legislation.

Therefore, mixed araça and marolo jam stored for up to 12 months can still be consumed safely.

\section{Acknowledgements}

This project was supported by CNPq, CAPES, and FAPEMIG.

\section{References}

ALMEIDA, S. P. Cerrado: aproveitamento alimentar. Planaltina: EMBRAPA, 1998. 169 p.

ARAUJO, J. M. A. Oxidação de lipidios. Viçosa: Universidade Federal de Viçosa, 1994. 22 p.

ASSOCIATION OF OFFICIAL ANALYTICAL CHEMISTS - AOAC. Official Methods of Analysis of Association of Official Analytical Chemists. Arlington: Ed. Helrich, 1997. 1850 p.

BAZIMARAKENGA, B.;SIMARD, R. R.;LEUROX, G. D. Determination of organic acids in oil extracts by ion chromatography. Soil Biology and Biochemistry, v. 27, p. 349-356, 1995. http://dx.doi. org/10.1016/0038-0717(94)00178-4

BITTER, V.; MUIR, H. M. A modified uronic acid carbazole reaction. Analysis Biochemistry, v. 4, p. 330-334, 1962. http://dx.doi. org/10.1016/0003-2697(62)90095-7

BORGUINI, R. G.; TORRES, E. F. S. Tomatoes and Tomato Products as Dietary Sources of Antioxidants. Food Reviews International, v. 25, p. 313-325, 2009. http://dx.doi.org/10.1080/87559120903155859
BRAND-WILLIAMS, W.; CUVELIER, M. E.; BERSET, C. Use of a free radical method to evaluate antioxidant activity. Lebensm-Wiss U-Technolology, v. 28, p. 25-30, 1995.

BRASIL. Agência Nacional de Vigilância Sanitária. Resolução Normativa no 9, 10 de dezembro de 1978. Atualiza a Resolução $n^{\circ}$ 52/77 da antiga Comissão Nacional de Normas e Padrões para Alimentos - CNNPA. Diário Oficial da República Federativa do Brasil, Brasília, DF, 11 dez. 1978. Disponível em: <http://www. anvisa.gov.br>. Acesso em: 17 maio 2010.

BRASIL. Ministério da Saúde. Agência Nacional de Vigilância Sanitária. Resolução RDC ANVISA/MS nº 12, de 02 de janeiro de 2001. Regulamento técnico sobre os padrões microbiológicos para alimentos. Diário Oficial da República Federativa do Brasil, Brasília, DF, 10 jan. 2001. Disponível em: <http://www.anvisa.gov>. Acesso em: 04 jul. 2010.

CARDOSO, R. L. Estabilidade da cor de geleia de jambo (Eugenia malaccensis L.) sem casca armazenada aos $25^{\circ} \mathrm{C}$ e $35^{\circ} \mathrm{C}$ na presença e ausência de luz. Ciência e Agrotecnologia, v. 32, n. 5, p. 1563-1567, 2008. http://dx.doi.org/10.1590/S141370542008000500031

CARVALHO, J. A. Marolo: o doce sabor do cerrado; sugestões de cultivo. Machado: Folha Machadense, 2002.

CHANG, Q. et al. Effect of storage temperature on phenolics stability in hawthorn (Crotaegus pinnatifida var. Major) fruits and a hawthorn drink. Food Chemistry, v. 98, p. 426-430, 2006. http://dx.doi. org/10.1016/j.foodchem.2005.06.015

COUlTATE, T. P. Alimentos: a química de seus componentes. 3. ed. Porto Alegre: Artmed, 2004. 368 p.

DEWANTO, V. et al. Thermal processing enhances the nutritional value of tomatoes by increasing total antioxidant activity. Jounal Agricultural Food Chemistry, v. 50, p. 3010-3014, 2002. PMid:11982434. http://dx.doi.org/10.1021/jf0115589

DI STASI, L. C.; HIRUMA-LIMA, C. A. Plantas medicinais na Amazônia e Mata Atlântica. 2. ed. São Paulo: UNESP, 2002. 604 p.

DUBOIS, M. K. A. et al. Colorimetric method for determination of sugars and related substances. Analytical Chemistry, v. 28, n. 3, p. 350-355, 1956. http://dx.doi.org/10.1021/ac60111a017

EVANGELISTA, J. Tecnologia de alimentos. 2. ed. São Paulo: Atheneu, 2000. p. 231-232.

FENNEMA, O. R. Química de los alimentos. 2. ed. Saragoza: Acribia, 2000. 1258 p.

FERREIRA, D. F. Análises estatísticas por meio do SISVAR para Windows versão 4.0, São Carlos, S.P, 2000. In: REUNIÃO ANUAL DA REGIÃO BRASILEIRA DA SOCIEDADE INTERNACIONAL DE BIOMETRIA, 2000, São Carlos. Anais... São Carlos: EdUFSCar, 2000. p. 235.

GENOVESE, M. I. et al. Determinação do conteúdo de fenólicos totais em frutas. Revista Ciências Farmacêuticas, v. 39, p. 167-169, 2003.

GIANNAKOUROU, M. C.; TAOUKIS, P. S. Kinetic modeling of vitamin $\mathrm{C}$ loss in frozen Green vegetables under variable storage conditions. Food Chemistry, v. 83, n. 1, p. 33-41, 2003. http://dx.doi. org/10.1016/S0308-8146(03)00033-5

GOIÁS (Estado). Secretaria de Ciência e Tecnologia do Estado de Goiás - SIMEGI. Rede metereológica, estação 102, heliponto Goiânia. 2009. Disponível em: <http//www.sectec.org.go.br>. Acesso em: 28 jan. 2009.

INSTITUTE OF MEDICINE - IOM. Dietary reference intakes for calcium, phosphorus, magnesium, vitamin $\mathrm{D}$ and fluoride. Washigton: National Academic, 1997. 
INSTITUTE OF MEDICINE - IOM. Dietary reference Intakes for vitamim $A, K$, arsenic, boron, chromium, copper, iodine, iron, manganese, molibdenium, nickel, silicon, vanadium and zinc. Washigton: National Academic, 2001. p. 442-501.

INTERNATIONAL COMMISSION ON MICROBIOLOGICAL SPECIFICATIONS FOR FOODS - ICMSF. Microrganisms in food. 2. ed. Toronto: University of Toronto, 1983. $436 \mathrm{p}$.

JAIME, S. B. M. Embalagem de vidro com sistema de fechamento alternative para café solúvel. Boletim de Tecnologia e Desenvolvimento, v. 14, n. 1, p. 1-5, 2002.

LOPES, R. L. T. Manual para fabricação de geleias. Belo Horizonte: Fundação Centro Tecnológico de Minas Gerais, 1985. 42 p. (Série de Publicações Técnicas).

LORENZI, H. Árvores brasileiras: manual de identificação e cultivo de plantas arbóreas nativas do Brasil. 2. ed. Nova Odessa: Plantarum, 1998. $368 \mathrm{p}$.

MANICA, I. Frutas nativas, silvestres e exóticas 1: Técnicas de produção e mercado: abiu, amora-preta, araçá, bacuri, biriba, carambola, cereja-do-rio-grande, jabuticaba. Porto Alegre: Cinco Continentes, 2000. p. 91-128.

OETTERER, M.; REGITANO-d'ARCE, M. A. B.; SPOTO, M. H. F. Fundamentos de Ciências e Tecnologia de Alimentos. Barueri: Manole, 2006. 612 p.

ORDONEZ, J. A. et al. Tecnologia de alimentos: componentes dos alimentos e processos. Porto Alegre: Artmed, 2005. 294 p.

RADA-MENDOZA, M.; OLANO, A.; VILLAMIEL, M. Furosine as indicator of Maillard reaction in jams and fruit based infant foods. Food Chemistry, v. 50, n. 14, p. 4141-4145, 2002. PMid:12083898. http://dx.doi.org/10.1021/jf0201024

RADA-MENDOZA, M. et al. Formation of hydroxymethylfurfural and furosine during the storage of jams and fruit based infant foods. Food Chemistry, v. 88, p. 605-609, 2004. http://dx.doi. org/10.1016/j.foodchem.2003.07.002
ROESLER, R. et al. Atividade antioxidante de frutos do cerrado. Revista Ciência Tecnologia de Alimentos, v. 27, n. 1, p. 1004-1019. 2007.

SILVA, F. A. et al. Exsudação de ácidos orgânicos em rizosfera de plantas daninhas. Planta Daninha, v. 19, p. 193-196, 2001. http://dx.doi. org/10.1590/S0100-83582001000200006

SNOWDON, J. A.; OLIVER, D. O. Microorganism in honey. International Journal of Food Microbiology, v. 31, p. 1-23, 1996. http://dx.doi.org/10.1016/0168-1605(96)00970-1

SOLON, S. et al. Free radical scavenging activity of Lafoensia pacari. Journal of Ethnopharmacology, v. 72, p. 173-178, 2000. http:// dx.doi.org/10.1016/S0378-8741(00)00233-6

TORREZAN, R. Preparo caseiro de geleias. Rio de Janeiro: Embrapa/ CTAA, 1997. 15 p.

VAN DEN BERG, A. J. et al. A novel formulation of metal íons and citric acid reduces reactive oxygen species in vitro. Journal of Wound Care, v. 12, p. 413-318, 2003. PMid:14648968.

WICKLUND, T. et al. Antioxidant capacity and colour of strawberry Jam as influenced by cultivar and storage conditions. Food Science and Technology, p. 387-391, 2005.

WILSON, E. D.; SANTOS, A. C.; VIEIRA, E. C. Energia. In: DUTRA OLIVEIRA, J. E.; SANTOS, A. C.; WILSON, E. D. Nutrição básica. São Paulo: Savier, 1982. p. 80.

ZAFRILLA, P.; FERRERES, F.; TOMS-BARBERN, A. Effect of processing and storage on the antioxidant ellagic acid derivatives and flavonoids of red raspberry (Rubus idaeus) jam. Journal of Agricultural and Food Chemistry, v. 49, n. 8, p. 3651-3655, 2001. PMid:11513642. http://dx.doi.org/10.1021/jf010192x

ZIELISKI, H.; KOZOWSKA, H. Antoixidant activity and total phenolics in selected cereal graims and their different morphological fractions. Journal Agricultural Food Chemistry, v. 48, p. 2008-2016, 2000. http://dx.doi.org/10.1021/jf990619o 